\title{
Integrating Sciences to Sustain Urban Ecosystem Services
}

\author{
L Lundy ${ }^{1 *}$ and R Wade ${ }^{2}$ \\ ${ }^{1}$ Urban Pollution Research Centre, Middlesex University, The Burroughs, Hendon, NW4 4BT, UK. \\ Email: L.Lundy@mdx.ac.uk. Telephone: +44 (0)20 84116361. Fax: +44 (0)20 84116774. \\ ${ }^{2}$ Urban Water Technology Centre, University of Abertay Dundee, Bell Street Dundee, DD1 1HG, UK. \\ Email: R.Wade@abertay.ac.uk. Telephone: +44 (0)1382 308 650. Fax: +44 (0)1382 308117. \\ * Corresponding author
}

\begin{abstract}
Effective water management within urban settings requires robust multi-disciplinary understanding and an appreciation of the value added to urban spaces by providing multi-functional green-blue spaces. Multi-functional landscapes where ecosystem service provisions are 'designed-in' can help 'transition' cities to more sustainable environments which are more resilient to changing future conditions. With benefits ranging from the supply of water, habitat and energy to pollutant removal, amenity and opportunities for recreation, urban water bodies can provide a focal point for reconnecting humans and nature in otherwise densely built-up areas. Managing water within urban spaces is an essential infrastructure requirement but has historically been undertaken in isolation from other urban functions and spatial requirements. Increasingly, because of the limits of space and need to respond to new drivers (e.g. mitigation of diffuse pollution), more sustainable approaches to urban water management are being applied which can have multiple functions and benefits. This paper presents a review of ecosystem services associated with water, particularly those in urban environments and uses the emerging language of ecosystem services to provide a framework for discussion. The range of supporting, provisioning, regulating and cultural ecosystem services associated with differing types of urban water bodies are identified. The developed matrix is then used to evaluate the results of a series of social, ecological and physical science studies co-located on a single stretch of a restored urban river.
\end{abstract}

Key Words: Urban ecosystem services, Water, Multi-functional landscapes

\section{Introduction}

With the theme of World Water Day 2011 being urban water management and the development of the Intergovernmental Panel on Biodiversity and Ecosystem Services, now is a timely opportunity to review the role of water in urban areas using the emerging language of ecosystem services. Urban areas are of increasing importance as a human habitat. Of the 6.91 billion people on earth, 3.49 billion (or $50 \%$ ) are reported to live in urban areas, with the urban population predicted to increase by a further 2.8 billion by 2050 (UN, 2009). Urban population growth is predicted to be greatest in 'developing' counties, exceeding urban growth in 'developed' countries by a factor of almost five (UN Habitat, 2008). Of this rapidly growing urban population, approximately $33 \%$ are reported to live in slum areas. It is within this context that the Brundtland (1987) definition of sustainable development (meet the needs of the present without compromising the ability of future generations to meet their own needs) has never seemed more urgent or challenging.

Publication of the Millennium Ecosystem Assessment (MEA) has led to increasing international awareness of the importance of the services, goods and benefits gained from the environment that benefit humans, and the need to recognise and value these goods and services within policy development and implementation (MEA, 2005). This led directly to the concept of ecosystem services, an emerging transdisciplinary approach providing a framework through which the benefits accrued from ecosystem services can be interrogated from multiple perspectives in an approach consistent with systems thinking. Whilst the drive to develop and implement a more integrated approach is at the forefront of urban water management research (e.g. Makropoulos et al., 2008) and legislation (e.g. EU Water Framework Directive (WFD), 2000), this approach still effectively 'segregates' water management from other components of urban landscape. In contrast, the ecosystem service approach facilitates the integration of information from both physical and social sciences on a diversity of aspects that contribute to human health and well-being. However, rather than an alternative management strategy, an ecosystem services approach can be seen as an integrating mechanism to inform policy making and delivery from a more holistic perspective. 
As a contribution to the debate on urban water management, this paper considers the multiple roles of water components in urban areas in terms of the supporting, provisioning, regulating and cultural ecosystem services (the key types of ecosystem services identified in the MEA) it can deliver at a local scale. This analysis leads to the development of an urban water ecosystem services matrix which is used to support an evaluation of the findings of a series of social, environmental and physical science studies implemented within a single case study location. The paper concludes with a consideration of the barriers to and opportunities for facilitating transdisciplinary research as a fundamental approach to underpin the development of the robust database required to ensure 'today's solution' is not 'tomorrow's problem'.

\section{Urban water drivers}

Water is present in urban areas in a variety of natural (e.g. rivers, wetlands and groundwater), artificial (for example, canals and sustainable drainage systems) and 'hybrid' (e.g. restored rivers) forms which exist on a range of spatial and temporal scales. Whilst urban watercourses account for a small proportion of the total length of rivers, they are of disproportionate importance due to their high public profile (RCEP, 2007) and the high degree of both direct (e.g. culverting) and indirect (e.g. erosion driven channel enlargement) morphological change (Mooney et al., 2009, Chin, 2006). For example, of the 2362 water bodies (areas of water which have similar levels of modification and surrounding land-use) identified across Scotland, 258 water bodies run to some extent through urban areas (Bromley, 2010). Of these 258 water bodies, only 50 water bodies (equating to $2 \%$ of the total number) are completely contained within urban areas.

Recent years have seen a trend toward protection and improvement of the urban water environment. This arises from a need in many countries to conserve and re-use water (e.g. Water Sensitive Urban Design (WSUD) in Australia and Low Impact Development (LID), in the USA). Both WSUD and LID advocate the need to incorporate all aspects of water into urban development and planning from the earliest stages. This is to maximise the opportunities for context sensitive water cycle management (Lloyd, 2002), effectively encouraging the continuation of natural water processes within an urban environment. In addition, urban river restoration projects have arisen from a desire to improve the urban environment and better manage urban open spaces in response to water quality (e.g. EU WFD, 2000) water quantity (e.g. EU Floods Directive (EU 2007)), conservation (e.g. UN Convention on Biodiversity, 1992) and quality-of-life agendas (e.g. Defra, 2007). There are many large and small scale examples of river restoration globally (e.g. Bernhartd et al., 2005 for synthesis of projects in the USA). Parallel efforts are occurring in terms of promoting the use of surface water and stormwater management through the promotion of stormwater best management practices (BMPs) in many countries (also known as sustainable urban drainage systems (SUDS)). Stormwater BMPs are a wide range of constructed systems from wetlands and ponds to infiltration trenches and swales which mimic natural hydrological processes including infiltration, detention, groundwater recharge and evapotranspiration (Yang and LI, 2010, Villarreal et al., 2004).

Many of these approaches to urban water management are driven by practical requirements to, for example, re-use water, 'slow the flow' generated by rainfall in impermeable urban environments and mitigate flooding/inundation from small-scale storm events. Further drivers include the need to reduce the pressure on existing sewer infrastructure and wastewater treatment plants in terms of both capacity and treatment efficiency as well as the need to control urban diffuse pollution as part of the approach to achieving ambitious EU WFD objectives. All of the approaches presented above represent more sustainable ways to manage urban water resources but also provide an opportunity to support and enhance ecosystem service provision in urban settings.

\section{Ecosystem services}

The MEA divides the services provided by the environment which benefit people into four categories, acknowledging that these categories can and do overlap extensively (MEA, 2005). The application of the four categories (provisioning, regulating services, cultural and supporting) to the services, goods and benefits associated with urban water bodies are discussed in the following sections.

\section{Supporting services}


The MEA (2005) describes supporting services as the processes which are essential for the production of all provisioning, regulating and cultural services. Supporting services differ from the other types of services in that their impacts on humans are indirect and/or occur over very long periods of time. Examples include primary production, oxygen production, soil formation, water cycling and habitat provision (MEA, 2005, Table 1). Primary production is at the base of all food chains. Whilst the process of urbanisation is reported to reduce regional net primary productivity (Deyong et al., 2009, Milesi et al., 2003), the photosynthetic activities of aquatic and terrestrial vegetation sustained by urban water bodies contribute to the mitigation of the net loss of primary productivity. However, the extent to which the primary productivity of water bodies achieves this has yet to be quantified on a city scale. Similarly, terrestrial and aquatic vegetation contributes to oxygen levels within the atmosphere and water bodies (Nakova et al., 2009) but data on the magnitude of this impact specifically in relation to urban water bodies could not be sourced. Lakes, streams and rivers may all play a key role in the formation and retention of alluvial soils and sediments, with for example, soil accretion rates of $1 \mathrm{~cm}$ year ${ }^{-1}$ reported for coastal marshes (Nyman et al., 1990) and 1.0 to $7.6 \mathrm{~mm} \mathrm{yr}^{-1}$ for flood plains affected by periodic floods (Saint-Lauent et al., 2008). The impact of urban areas on river bank sediments in terms of increased metal concentrations has been reported (de Miguel et al., 2005) with Scharenbroch et al., (2005) suggesting that urban soils can be physically, chemically and biologically distinguished from other soil types.

Surface and ground water bodies play a key role in water cycling, and hence the renewable provision of freshwater (Postel and Carpenter, 1997), as receivers of rainfall through both direct (deposition) and indirect (runoff) routes. Surface water bodies may recharge groundwater (and vice-versa), returning water to the atmosphere directly (evaporation) and indirectly (evapotranspiration), with the relative importance of these mechanisms varying greatly in relation to factors such as climate and level of vegetative cover (Krüger and Pearlmutter, 2008). Urban development is associated with an increase in ground impermeability due to the development of roads, pavements and buildings etc and a consequent reduction in vegetative cover. This has profound effects on the functioning of the water cycle, reducing the recharge of groundwater and other surface water bodies with potential impacts on both water supply and soil stability (e.g. rapid subsidence of areas of Mexico city due to over abstraction of groundwater (Osmanoğlu et al., 2010)). Further impacts include reduction of evapotranspiration processes and increased volumes of runoff (Madlener and Sunak, 2010, Shi et al., 2007). In relation to the provision of habitat, urban water components such as garden ponds and stormwater BMPs can make a crucial contribution, with both the water body and its associated vegetation providing habitat for a range of flora and fauna (Kazemi et al., 2009, Davies et al., 2004) including pollinators (a further supporting service). As well as direct habitat provision, the strategic location of urban water components can also facilitate habitat provision contributing to landscape connectivity objectives (Le Viol et al., 2009).

\section{Provisioning services}

Provisioning services relate to the production of products from ecosystems, including water, food, fuel and genetic resources (MEA, 2005, Table 1)). As a function of their impermeable nature, urban areas are excellent at generating water through their detention of rainfall, enabling large volumes to be generated quickly (Semadeni-Davies et al., (2008); Carter and Jackson (2007)). Rainfall (or stormwater) runoff is typically viewed as wastewater and its management a major challenge; rain can fall in the wrong place at the wrong time in relation to meeting domestic, irrigation and industrial water needs. Stormwater runoff mobilises pollutants deposited on surfaces from a range of sources (e,g, traffic, atmospheric deposition, wear and tear of road materials) (Karlsson et al., 2010, Eriksson et al., 2007). Further sources of stormwater pollution include 'misconnections' (where foul sewage is wrongly plumbed into surface water sewers) with the discharge of combined sewer overflows (CSOs) into receiving water bodies causing further degradation of urban water quality. Whilst the challenges of using stormwater as a contribution to meeting local water needs abound, current and projected water demands are of such scale (1.2 billion people currently lack access to clean drinking water with up to two-thirds of the world's population predicted to be affected by water scarcity by 2100 (Rijsberman, 2006)), the generation of stormwater by cities is now beginning to be seen as a valuable resource (Berndtsson, 2010). Innovative thinking is required to enable such a paradigm shift to be realised. However, the proximity of water supply and demand in urban areas should be embraced and opportunities for its sustainable exploitation sought. Urban water bodies do already contribute to the provision of water within urban environments (e.g. $80 \%$ of the drinking water in London (UK) comes 
from its rivers (Mayor of London, undated). However, the use of stormwater to fulfil a suite of functions from groundwater recharge to irrigation and water supply is an underutilised resource.

Whilst urban water bodies can and do provide a range of foods, elevated pollutant levels have also been reported in foods originating from urban water bodies (e.g. a ban on commercial fishing in Sydney harbour following the detection of elevated levels of dioxins in fish and crustacean (Rudge et al., 2008). Within an EU context, the on-going implementation of the EU WFD (2000) is anticipated to mitigate (or at least halt) degradation of urban water body quality. However, the impact of sediment on surface water quality should not be overlooked particularly in an urban water context. Sediments can act as both pollutant source and sink, with the point discharge of storm flows into urban watercourses re-suspending previously settled sediments and associated pollutants with deleterious impacts on overlying water quality (Crahill et al., 1999, Scholes et al., 2008, Cho et al., 2010).

Water has been used to generate power throughout the last two millennia. On a global basis, hydropower accounts for $19 \%$ of electricity production, with the largest producers of hydroelectricity including China, Canada and Brazil (USGS, 2010). Large hydroelectric plants are typically constructed out with urban areas due to the need for dam and reservoir construction. However, as the most useable land (in terms of elevation, water supply and access) have already be used, the rate of dam construction has fallen over the last 30 years with the USGS (2010) predicting that the future for hydroelectricity will be associated with the construction of small-scale community hydroelectric plants. The development of smaller hydroelectric systems which can be 'run of the river' installations (i.e. not requiring the construction of dams) facilitates their use within urban areas. A review of the use of the small hydropower sector within EU Member States by Punys and Pelikan (2006) identified 17200 plants in operation. Whilst the location of these plants is not clear, the use of small scale hydropower systems in urban areas is being examined in several cities, for example, the use of micro-hydroelectric power plants in Portland (USA) (JDC, 2010) and the use of a mini-hydropower plant in Grenoble (France) (SESAC, undated).

Further provisioning services include the supply of genetic information used in animal and plant breeding, biochemicals (used for pharmaceuticals) and ornamental resources (e.g. flowers and shells) (Wang et al., 2010, Decaëns et al., 2006, MEA, 2005). As noted earlier, urban water bodies are typically in receipt of diffuse pollution from a range of sources. Whilst this may at first appear to exclude the generation of services such as the supply of genetic information, the presence of species able to tolerate and/or degrade elevated pollutant levels offers interesting opportunities in relation to, for example, the field of microbial bioremediation (Galvao et al., 2005). The potential for plants, bacteria and fungi which can degrade or immobilise organic and inorganic pollutants has received considerable attention (Desai et al., 2010, Bender and Phillips, 2004), with drivers such as the EU Environmental Quality Standards Directive (2008) providing a strong driver for the development of cost-effective technologies to mitigate identified and emerging priority substances. 
Table 1 Examples of ecosystem services associated with urban water components together with ecosystem goods, benefits and possible units of measure.

\begin{tabular}{|c|c|c|c|}
\hline $\begin{array}{c}\text { Categories of } \\
\text { ecosystem services }\end{array}$ & $\begin{array}{c}\text { Types of ecosystem } \\
\text { services }\end{array}$ & $\begin{array}{c}\text { Ecosystem goods and } \\
\text { benefits }\end{array}$ & $\begin{array}{c}\text { Example units of } \\
\text { measurement }\end{array}$ \\
\hline \multirow[t]{5}{*}{ Supporting services } & Primary production & \multirow{5}{*}{$\begin{array}{l}\text { The goods and benefits of } \\
\text { sustaining services are their role } \\
\text { in facilitating other services to } \\
\text { take place }\end{array}$} & $\mathrm{g} \mathrm{C} \mathrm{m}^{-2}$ \\
\hline & Production of oxygen & & $\mathrm{g} \mathrm{O}_{2} \cdot \mathrm{m}^{-2}$ \\
\hline & Soil formation & & $\mathrm{cm}_{\text {year }}^{-1}$ \\
\hline & Water cycling & & $\%$ permeability \\
\hline & Provisioning of habitat & & hectares \\
\hline \multirow[t]{4}{*}{ Provisioning services } & Food & Meat and vegetables & tonnes/hectare \\
\hline & Water & Potable and non-potable water & litres/hectare \\
\hline & Renewable energy & Hydropower & mega watts \\
\hline & Genetic resources & Pollutant degrading species & $\mathrm{cfu} / \mathrm{ml}$ \\
\hline \multirow[t]{4}{*}{ Regulating services } & Climate regulation. & Reduced urban temperatures & ${ }^{\circ} \mathrm{C}$ \\
\hline & Water regulation & Reduced runoff volume / velocity & $\mathrm{m}^{3} ; \mathrm{ms}^{-1}$ \\
\hline & Erosion control & Stabilisation of sediments & $\mathrm{g} / \mathrm{m}^{2}$ \\
\hline & Water purification & Removal of pollutants & $\mathrm{mg} / \mathrm{L}$ \\
\hline \multirow[t]{4}{*}{ Cultural services } & Spiritual value & Mental well being & $\begin{array}{l}\text { Numbers of users (reduced } \\
\text { demand on mental health } \\
\text { services) }\end{array}$ \\
\hline & Educational value & $\begin{array}{l}\text { Increased environmental } \\
\text { awareness }\end{array}$ & $\begin{array}{l}\mathrm{Kg} \text { (reduced littering of water } \\
\text { bodies) }\end{array}$ \\
\hline & Aesthetics & Increased house prices & $\%$ (increase in house price) \\
\hline & Recreation & Physical well being & $\%$ (reduced levels of mortality) \\
\hline
\end{tabular}

\section{Regulating services}

Regulating services relate to the goods and benefits generated through the regulation of ecosystem functions including processes such as climate regulation, water regulation, water purification, erosion control and pollination (de Groot et al., 2010, MEA, 2005, Table 1). Urban water bodies contribute to the delivery of many of these ecosystem services. However, whilst there is an established evidence base on. for example, the role of stormwater BMPs in the regulation and purification of water (e.g. DayWater BMP catalogue, 2005), the interpretation of this evidence in terms of ecosystem services is only beginning to emerge. Whilst their performance is reported to vary in relation to a range of factors including system type, influent loading and catchment characteristics, the water quantity and quality role of a range of stormwater BMPs is well documented to reduce surface water volumes, velocities and pollutant loadings (Jefferies et al., (1999), Hatt et al., (2006), Merete Muthanna et al., (2007)). Less well understood is the potential for stormwater BMPs to provide a range of further regulating services, such as mitigation of the urban heat island, carbon sequestration, noise regulation and pollination. Whilst different types of stormwater BMPs are appropriate in different situations, each can offer 'added value' in terms of ecosystem service provision.

Whilst many urban watercourses were channelized to promote the transport of flood waters away from built-up areas, restoring urban rivers is now recognised as offering a cost-effective approach to flood management through enhancing local flood attenuation, watercourse flood storage capacity and reduced downstream flooding (EA, 2002). The breaking-down of concrete river channels also reopens the potential for further processes such as groundwater recharge to take place and provides habitat for the movement and migration of plant, animal and insect species (Wilby and Perry 2006) both as a potential adaptation to climate change and as contributions to biodiversity and conservation objectives. Urban rehabilitation projects have been identified to provide opportunities to access nature (Landrigan et al. 2004) and the provision of mental and physical health benefits typically associated with urban green space (see section on Cultural Services). Whilst these benefits have not yet necessarily been discussed in terms of ecosystem services, it is the provision of such services and goods that are identified as drivers behind the increase in the number of river restoration programmes initiated in recent years (Skinner and Bruce-Burgess, 2005). 
Together with urban watercourses, urban lakes and ponds can act as heat sinks contributing to mitigation of the urban heat island effect (Defra 2010), with the use of wet pavements also reported to reduce day and night time temperatures in urban areas (Yamagata et al., 2008). The vegetation associated with urban water features can also contribute to insulation (e.g. green roofs) and cooling (Castleton et al., 2010), linking into the concepts of green infrastructure, urban greening and low impact development (Montalto et al., 2007), as well as providing habitat for pollinators.

\section{Cultural services}

Cultural services refer to the nonmaterial benefits humans gain from ecosystem services such as spiritual, aesthetic and educational values, and opportunities for recreational activities (MEA, 2005, Table 1). That natural environments supply more than the necessities of food and water, but additionally provide restorative and preventative health benefits, has been reported for centuries (see review by Ward Thompson, 2010). In the context of increasing obesity and mental illness reported in many countries (Minet Kinge and Morris, (2010), Pieniak et al., (2009), NHS, 2010), the role of green spaces in urban areas in providing a relatively low-cost contribution to improving and maintaining physical and mental health has become a focus of attention for both researchers and policy-makers (van den Berg et al., 2010, Maas et al., 2006).

Recent research by White et al., (2010) reported that natural and built environments containing water are associated with higher preferences than either environment without water. Of particular note is their finding that built environments containing water were as preferred as purely green space, suggesting that the presence of water confers some level of intrinsic value irrespective of location. Restoring urban rivers is seen as an opportunity to connect urban communities with nature and improve well-being through the provision of safe and attractive places for exercise, tranquillity and opportunities for education (EA, 2006). However, concerns over potential human health risks related to recreational users coming into contact with urban river sediment have also been raised (Scholes at al., 2008). Larger urban water bodies can provide opportunities for recreational activities such as boating, canoeing and fishing, with water bodies of all sizes providing attractive locations for more reflective and passive activities. Stormwater BMPs, for example, can (depending on the type of system) contribute to the provision of cultural services within both these active and passive categories. The role of BMPs in mitigating water quality and quantity is noted in the section on regulating services, with their potential to provide amenity, recreational and educational benefits providing the third corner of SUDS (BMP) triangle (a theoretical concept facilitating the selection of SUDS in relation to achieving combined water quantity, quality and amenity objectives (D'Arcy and Frost, 2001). Research on the social impact of BMPs found that residents living close to mature BMPs ponds not only valued the systems in terms of flood management but also their role in attracting wildlife and improving the landscape, with residents suggesting that homes located close to well-designed, managed, established BMPs would achieve a 10\% premium (Apostolaki, undated).

\section{Ability of selected urban water components to contribute to the delivery of identified ecosystem services}

The list of urban water components identified in Table 2 is not intended to be exhaustive but instead to be indicative of the main generic types and scales of water features found in urbanised areas. Channelized watercourses refer to open concrete channels from drainage channels up to river-scale systems, with natural/restored watercourses referring to similar types and scales of watercourses in which banks are not reinforced with concrete or the concrete-casing has been broken-down. Lakes and ponds refer to natural quiescent water bodies, with reservoirs and settlement ponds their artificial counterparts. Vegetated filters include systems such as small-scale constructed wetlands, swales and green roofs. The ability of each identified urban water component to contribute to a range of the ecosystem services generated is identified, where ' $\mathscr{\text { ' }}$ indicates the water component is considered to routinely contribute to the delivery of the identified service and ' $x$ ' indicates the urban water component is not considered to routinely contribute to its delivery.

From Table 2 it can be seen that all urban water types identified are considered to have the potential to contribute to the delivery of a range of ecosystem services. However, as data on the contribution of various water component types to deliver specific types of ecosystem services is scarce (and urban water-specific data scarcer still), it is not possible to add any quantification to the value assessments benchmarked below. The presence of vegetation in the natural and restored rivers, lakes and ponds 
and vegetated filters categories is considered to contribute to primary production and oxygen production and likewise the absence of vegetation within groundwater is responsible for its non contribution to these services. Whilst reservoirs and settlement tanks may be host to vegetation, these typically more managed systems are considered to make a less important contribution together with channelized water courses where flow velocities are not conducive to the establishment of permanent vegetation. Urban water components that are free to 'spill over' onto established flood plains (e.g. restored rivers) are considered to have the potential to contribute to soil formation. When considered in terms of supporting macro-flora and -fauna, all identified urban water components (with the exception of groundwater) are considered to have the ability to provide habitat, with all types of urban water components contributing to the functioning of the water cycle.

Table 2. Overview of selected urban water body components and their potential to contribute to the delivery of identified ecosystem services within an urban environment

\begin{tabular}{|c|c|c|c|c|c|c|c|}
\hline \multicolumn{2}{|c|}{ 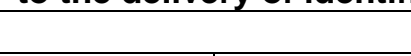 } & \multicolumn{6}{|c|}{ Type of urban water component } \\
\hline $\begin{array}{l}\text { Category of } \\
\text { ecosystem } \\
\text { service }\end{array}$ & $\begin{array}{c}\text { Type of } \\
\text { ecosystem } \\
\text { service }\end{array}$ & $\begin{array}{l}\text { Channelized } \\
\text { watercourse }\end{array}$ & $\begin{array}{l}\text { Natural and } \\
\text { restored } \\
\text { watercourse }\end{array}$ & $\begin{array}{l}\text { Lakes } \\
\text { and } \\
\text { ponds }\end{array}$ & $\begin{array}{c}\text { Reservoirs } \\
\text { and settlement } \\
\text { ponds }\end{array}$ & $\begin{array}{l}\text { Vegetated } \\
\text { filters }\end{array}$ & Groundwater \\
\hline \multirow[t]{5}{*}{ Supporting } & $\begin{array}{l}\text { Primary } \\
\text { production }\end{array}$ & $\mathbf{X}$ & $\checkmark$ & $\sqrt{ }$ & $\mathrm{X}$ & $\sqrt{ }$ & $\mathbf{x}$ \\
\hline & $\begin{array}{l}\text { Oxygen } \\
\text { production }\end{array}$ & $\mathbf{x}$ & $\sqrt{ }$ & $\sqrt{ }$ & $x$ & $\sqrt{ }$ & $x$ \\
\hline & $\begin{array}{l}\text { Soil } \\
\text { formation }\end{array}$ & $\mathrm{X}$ & $\sqrt{ }$ & $\sqrt{ }$ & $\mathrm{x}$ & $\mathrm{X}$ & $\mathrm{X}$ \\
\hline & Water cycle & $\sqrt{ }$ & $\checkmark$ & $\sqrt{ }$ & $\checkmark$ & $\sqrt{ }$ & $\sqrt{ }$ \\
\hline & Habitat & $\sqrt{ }$ & $\checkmark$ & $\sqrt{ }$ & $\sqrt{ }$ & $\checkmark$ & $x$ \\
\hline \multirow[t]{4}{*}{ Provisioning } & Food & $\checkmark$ & $\checkmark$ & $\checkmark$ & $\sqrt{ }$ & $\mathrm{X}$ & $\mathbf{X}$ \\
\hline & Water & $\checkmark$ & $\checkmark$ & $\sqrt{ }$ & $\sqrt{ }$ & $\mathrm{x}$ & $\checkmark$ \\
\hline & $\begin{array}{l}\text { Renewable } \\
\text { energy }\end{array}$ & $\sqrt{ }$ & $\sqrt{ }$ & $\mathrm{X}$ & $\sqrt{a}$ & $\mathrm{x}$ & $\mathbf{X}$ \\
\hline & $\begin{array}{l}\text { Genetic } \\
\text { resource }\end{array}$ & $\sqrt{ }$ & $\sqrt{ }$ & $\sqrt{ }$ & $\sqrt{ }$ & $\sqrt{ }$ & $\sqrt{ }$ \\
\hline \multirow[t]{4}{*}{ Regulating } & $\begin{array}{l}\text { Climate } \\
\text { regulation. }\end{array}$ & $\checkmark$ & $\sqrt{ }$ & $\sqrt{ }$ & $\sqrt{ }$ & $\sqrt{ }$ & $\mathrm{X}$ \\
\hline & $\begin{array}{l}\text { Water } \\
\text { regulation }\end{array}$ & $\sqrt{ }$ & $\sqrt{ }$ & $\sqrt{ }$ & $\sqrt{ }$ & $\sqrt{ }$ & $\checkmark$ \\
\hline & $\begin{array}{l}\text { Erosion } \\
\text { control }\end{array}$ & $\sqrt{ }$ & $\mathrm{X}$ & & $\sqrt{ }$ & $\sqrt{ }$ & $\sqrt{ }$ \\
\hline & $\begin{array}{l}\text { Water } \\
\text { purification }\end{array}$ & $\mathrm{X}$ & $\mathrm{X}$ & $\sqrt{ }$ & $\sqrt{ }$ & $\sqrt{ }$ & $\checkmark$ \\
\hline \multirow[t]{4}{*}{ Cultural } & $\begin{array}{l}\text { Spiritual } \\
\text { value }\end{array}$ & $\mathrm{X}$ & $\sqrt{ }$ & & $\sqrt{a}$ & $x$ & $\mathrm{X}$ \\
\hline & $\begin{array}{l}\text { Educational } \\
\text { value }\end{array}$ & $\mathrm{X}$ & $\sqrt{ }$ & $\sqrt{ }$ & $\checkmark$ & $\sqrt{ }$ & $\mathrm{X}$ \\
\hline & Aesthetics & $\mathrm{x}$ & $\sqrt{ }$ & $\sqrt{ }$ & $\sqrt{a}$ & $\sqrt{ }$ & $\mathrm{X}$ \\
\hline & Recreation & $\mathrm{X}$ & $\checkmark$ & $\sqrt{ }$ & $\sqrt{a}$ & $x$ & $\mathrm{X}$ \\
\hline
\end{tabular}

Key: ${ }^{a}$ associated with reservoirs only

With the exception of vegetated filters and groundwater, all other urban water components may contribute to the provision of food (e.g. fish and prawns), with only vegetated filters considered not to routinely contribute to the direct supply of water. However, it should be noted that the quality of water (and through association sediment and biota) in a channelized urban watercourse is of potential concern in relation to human consumption (see provisioning services section). The use of urban water components to generate renewable energy in the form of hydropower requires there to be a vertical fall of water for example, when a river runs down a hillside, over a waterfall, man-made weir or discharges from a reservoir, with the latter two scenarios potentially being the most relevant within an urban environment. All water components identified may be host to micro-organisms and hence provide a potential reserve for genetic resources. In terms of regulating services, open vegetated and un-vegetated water components can act as heat sinks contributing to the mitigation of the urban heat 
island effect, with the former category also contributing to cooling through evapotranspiration. All urban water systems are considered to contribute to the regulation of water through a range of processes including infiltration, detention and subsequent reduced velocity discharge. Erosion control is provided by the reinforced banks of channelized watercourses and settlement tanks, the larger storage volumes associated with lakes, reservoirs and groundwater and the buffering capacity of vegetation within vegetated filters. Mitigation of water quality is associated with natural and artificial quiescent water bodies (promoting sedimentation of particulate matter and associated pollutants), vegetated filters (processes including adsorption, settlement in association with flow reduction and microbial degradation) and groundwater (adsorption and microbial degradation). The flashy nature of artificial urban watercourses is not conducive to such pollutant removal processes and, whilst restored rivers are generally considered to mitigate water quality, there is little quantitative data available to support this hypothesis.

Groundwater and channelized urban watercourses and are not considered to offer great potential for the delivery of cultural services, being underground and artificial, typically linear features, respectively. Natural and restored water features such as rivers, lakes and ponds and larger quiescent water bodies such as reservoirs are typically viewed as aesthetically pleasing features, offering opportunities for reflection and contemplation (spiritual values) and recreation (e.g. boating and fishing). Together with vegetated filters, these urban water components can be host to a diversity of plant and animal life presenting a focal point for school and community-focussed activities such as pond dips, nature walks and conservation actions. As typically smaller-scale systems, vegetated filters in general are considered to offer limited opportunities for either spiritual enrichment or recreational activities but may present opportunities for small-scale nature studies.

\section{Application of an ecosystem services approach to a restored urban river}

In order to illustrate the utility of an ecosystem service approach to urban water environments, an evaluation of the ecosystem services, goods and benefits delivered by a restored section of the River Brent (Tokyngton Park, North London, UK) has been undertaken. The River Brent is a heavily urbanised river in receipt of both stormwater runoff and combined sewer overflows. In 1947, the meandering section of the River Brent which ran through Tokyngton Park was replaced with a ushaped contract channel as a flood management measure (Environment Agency for England and Wales, undated). Discussions between the Environment Agency for England and Wales (EA), the London Borough of Brent and the London Waterways Partnership led to the identification of the Tokyngton Park site for as appropriate for a river restoration programme. Following its completion in 2003, the urban water components present in Tokyngton Park include a section of channelized watercourse (retained from the original channel), a restored river and a small wetland (vegetated filter) (see Figure 1).

Both prior to and following restoration, this section of the Brent has been the focus of a range of independently implemented projects including evaluations of its ecology (England, 2004, and McMullen, 2007), geomorphology (EA, undated, McMullen, 2007), social impact (Ahmed, 2007), public perception (Apostolaki, 2007) and sediment dynamics and sediment quality (Adeyemi et al., 2009). Together with observations made on-site by the authors during several sampling trips over the time period 2005-2010, data generated through these studies form the basis for the assessment presented in Table 3 (cells shaded grey). Where data was not available, data sourced from the literature has been used to inform an estimate of whether identified service is delivered (un-shaded cells in Table 3).

The ecosystem services potentially delivered by each urban water component are identified in columns 3,5 and 7 of Table 3 (taken from Table 2), with columns 4,6 and 8 presenting an assessment of whether services identified are generated in practice. In relation to supporting services, each urban water component is considered to contribute to the provision of habitat although site specific ecology data was only available for the restored river and channelized components (England 2004 and McMullen, 2007). From Table 3 we can see that supporting services are better provided by the more naturally functioning 'restored' features at the site. For example the restored river contributes to all of the supporting services listed in Table 3. McMullan (2007) found biological water quality (based on macro-invertebrate counts) within the restored habitat was better than in the adjacent channelized section indicating that river restoration does lead to an improved habitat. These results support the findings of research by England completed before (2002) and after (2003 and 2004) the 
river restoration programme which also reported an improvement in habitat. However, later work by McMullen (2007) reported macro-invertebrate scores in 2007 which were similar to those taken in 2004 , indicating that there had been no further improvement in habitat quality. A continued input of surface runoff from the surrounding urban environment and input from CSOs were identified as contributing factors. All three urban water components were observed to receive rainfall and runoff indicating that all components contribute to the functioning of the urban water cycle. Whilst the channelized section are not anticipated to contribute to primary production, oxygen production or soil formation, the identified studies did not include measurements of these parameters and therefore these assumptions cannot be verified. The presence of vegetation in the restored river section and wetland area supports the assumption that these components will contribute to the delivery of primary production and oxygen production. Evidence overbank flows in the restored river section (in the form of river debris and trash collected in trees at overbank height) is indicates that the river does flow over the floodplain offering the potential for a contribution to the service of soil formation.

With respect to provisioning services, the channelized section and restored river components are identified to have the potential to generate food, water, renewable energy and genetic resources. Ahmed (2007) undertook a qualitative survey of the restored river section which included the identification of recreational activities undertaken by park users, and their perceptions of the social and visual values of the restoration work on the river. Of the respondents surveyed, none identified any of the activities suggesting that the restored river does not currently deliver these provisioning goods and benefits. Whilst the use of the channelized section and wetland were not included within the scope of the questionnaire, it is suggested that these sections do not deliver provisioning services. Further evidence in relation to the delivery of renewable energy in the form of hydropower is generated from the fact that no installations of the type required to generate hydropower were observed on-site.

Table 3. Overview of River Brent case study and potential to contribute to the delivery of identified ecosystem services within an urban environment

\begin{tabular}{|c|c|c|c|c|c|c|c|}
\hline \multirow{3}{*}{$\begin{array}{l}\text { Category of } \\
\text { ecosystem } \\
\text { service }\end{array}$} & \multirow{3}{*}{$\begin{array}{l}\text { Type of } \\
\text { ecosystem } \\
\text { service }\end{array}$} & \multicolumn{6}{|c|}{ Types of urban water component in Tokyngton Park } \\
\hline & & \multicolumn{2}{|c|}{$\begin{array}{l}\text { Channelised } \\
\text { watercourse }\end{array}$} & \multicolumn{2}{|c|}{$\begin{array}{c}\text { Vegetated } \\
\text { Filters }\end{array}$} & \multicolumn{2}{|c|}{$\begin{array}{c}\text { Natural and restored } \\
\text { watercourse }\end{array}$} \\
\hline & & Potential & Actual & Potential & Actual & Potential & Actual \\
\hline \multirow[t]{5}{*}{ Supporting } & $\begin{array}{l}\text { Primary } \\
\text { production }\end{array}$ & $\mathrm{X}$ & $X$ & & & & \\
\hline & $\begin{array}{l}\text { Oxygen } \\
\text { production }\end{array}$ & $\mathbf{X}$ & $X$ & & & & \\
\hline & Soil formation & 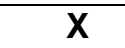 & $X$ & $X$ & $X$ & & \\
\hline & Water cycle & & & & & & \\
\hline & Habitat & & & & & & \\
\hline \multirow[t]{4}{*}{ Provisioning } & Food & & $\mathbf{X}$ & $X$ & $X$ & & $\mathbf{X}$ \\
\hline & Water & & $x$ & $\mathrm{X}$ & $X$ & & $x$ \\
\hline & $\begin{array}{l}\text { Renewable } \\
\text { energy }\end{array}$ & & $\mathrm{X}$ & $X$ & $X$ & & $x$ \\
\hline & $\begin{array}{l}\text { Genetic } \\
\text { resource }\end{array}$ & & $\mathrm{X}$ & & $X$ & & $x$ \\
\hline \multirow[t]{4}{*}{ Regulating } & $\begin{array}{l}\text { Climate } \\
\text { regulation. }\end{array}$ & & & & & & \\
\hline & $\begin{array}{l}\text { Water } \\
\text { regulation }\end{array}$ & & & & & & \\
\hline & $\begin{array}{l}\text { Erosion } \\
\text { control }\end{array}$ & & & & & $\mathbf{X}$ & $x$ \\
\hline & $\begin{array}{l}\text { Water } \\
\text { purification }\end{array}$ & $\mathbf{X}$ & $X$ & & & $X$ & $X$ \\
\hline \multirow[t]{4}{*}{ Cultural } & Spiritual value & $X$ & $X$ & $\mathbf{X}$ & $\mathbf{X}$ & & \\
\hline & $\begin{array}{l}\text { Educational } \\
\text { value }\end{array}$ & $X$ & $X$ & & $\mathrm{X}$ & & $X$ \\
\hline & Aesthetics & $\mathbf{X}$ & $\mathbf{X}$ & & & & \\
\hline & Recreation & $X$ & $X$ & $X$ & $\mathbf{X}$ & & \\
\hline
\end{tabular}


All three water components were anticipated to contribute to climate regulation through processes such as evaporative cooling and evapotranspiration (restored river and wetland only) although none of the studies specifically monitored these aspects. All three components are all considered to contribute to water regulation through processes such as retention of elevated flows reducing surface flooding (observed in both the restored and channelized section during wet weather events). Whilst the channelized section and wetland components are considered to contribute to erosion control, the restored rivers 'naturalised' river banks were highly eroded supporting the assumption that the restored river section was not resilient to elevated flows. Whilst water quality was not determined, the initial results of a sediment sampling campaign indicate that the concentrations of a range of heavy metals in sediment remain do not vary considerably between the channelized and restored sections. The wetland component was not monitored however there is an extensive literature base on the pollutant removal performance of wetland systems and on this basis the wetland is predicted to deliver water quality benefits.

In relation to the delivery of cultural services, as aims of the river restoration programme include encouraging recreation, improving visual amenity value, engaging the community in nature conservation and reducing crime (EA, undated), indicates that the channelized section (either pre- or post-completion of the downstream restoration programme) does not deliver any clear cultural goods or benefits. The EA's report indicates that the restored river section has achieved several of its objectives including engaging the local community with nature and improved visual amenity value. The results of park users survey (Ahmed, 2007) support these findings, also indicating that the restored river section provided a better opportunity for play, and was perceived by the respondents to be safer, more attractive and better for wildlife. Whilst the wetland area was not included in the park user survey, the vegetation is well established suggesting that it has aesthetic value. However, as the neighbouring restored river section was not identified as a site for educational activities, it is considered that these goods are currently exploited within a wetland context.

Whilst the individual studies are each of research and practical value, when collated and compared they provide a more holistic analysis of the impact of the river restoration programme, adding value and insight to the multiple benefits arising from a local park enhancement scheme. This integration of findings from a range of social, ecological and physical science studies within a single framework is considered to be of value to policy makers and practitioners through facilitating understanding of the wide-ranging benefits of environmental protection. Results may also be used to inform the development of land management plans with a view to enabling the delivery of further ecosystem services (e.g. potential for the weir located in the channelized section to generate hydropower) and support researchers in the development of transdisciplinary research approaches through an enhanced awareness of the multifunctional aspects of, for example, urban rivers.

\section{Conclusions}

As an approach to informing the conservation of ecosystems, the MEA (and its framework to support the evaluation and integration of services, goods and benefits generated by ecosystems) continues to have considerable impact on a national and international scale. This paper uses the emerging language of ecosystem services to consider the role of urban water components to contribute to the delivery of a range of ecosystem services, goods and benefits. Quantitative and/or qualitative data on the contribution of water components located in urban areas to the delivery of ecosystem services is scarce. However, knowledge derived from papers published in a range of disciplinary fields strongly indicate that urban water components contribute to the delivery of ecosystem services in all of the MEA categories, supporting the view that urban water bodies should be seen as multifunctional components of urban space.

A key aspect of this conclusion is the diversity of scientific, policy and practitioner disciplines from which information has been drawn, including social science, psychology, geomorphology, hydrology, environmental science, ecology, government departments and environmental regulators. Also of note is the finding that despite the completion of several single-discipline studies on the same case study site, it was only possible to qualitatively comment on the provision of ecosystem services in a few cases. Whilst acknowledged to be a single case study site, these findings compliment each other, providing support for the implementation of a transdisciplinary research approach. However, transdisciplinary research has yet to emerge as a fully respectable research approach within many 
academic communities. Many funding bodies do now support knowledge transfer activities and are taking part in initiatives which promote co-funded research across the disciplines, but the continued emphasis of funding along single discipline lines means that for many transdisciplinary research still appears to be 'on the edge' of scientific respectability. In order to approach this challenge and position transdisciplinary research in the centre of scientific respectability rather than 'on the periphery' it is imperative that we bring together discipline specific expertise to address fundamental and applied problems in a holistic way. One approach to addressing this would be the development of a Transdisciplinary Research Institute or Society, akin to the Royal Society of Chemistry or Institute of Physics with its own peer-review journal. The development of a high profile body which could represent and promote research and researchers keen to cross traditional single discipline divides would raise awareness and the prestige of transdisciplinary working. In providing an internationally recognised framework which facilitates transdisciplinary research, the ecosystem services approach offers an exciting mechanism to support researchers in tackling research questions that require thinking out with traditional scientific boundaries. Ensuring quality-of-life for future generations facing an uncertain future is a challenge unlikely to be fully addressed by one discipline alone. The opportunity to fully exploit this approach to collaborative working should not be lost.

\section{Acknowledgements}

Many of the ideas presented in this paper were explored and debated with participants in the Transdisciplinary Seminar Series "ISSUES - Integrating Sciences to Sustain Urban Ecosystem Services". The seminars were funded jointly by ESRC/NERC/EPSRC (RES-496-26-0048) and ran from 2008 2010. This funding is gratefully acknowledged, as is the contribution of all ISSUES delegates. Research undertaken at the case study site on the River Brent by several students including Andrew McMullan and Stella Apostalaki (Abertay Dundee), Abiodun Adeyemi (Middlesex) and Madiha Ahmed (Queen Mary, University of London) is referred to in this paper and their work is hereby acknowledged.

\section{References}

Adeyemi A., Scholes L., Revitt DM., Jones H., \& Faulkner HP. (2009) The Xenobiotic impact of sedimentary metals in an urban river. Extended abstract paper in: Proceedings of the International Conference on Xenobiotics in the Urban Water Cycle (XENOWAC 2009). Paphos, Cyprus, March 11132009.

Ahmed, M.S. (2007) Public Perceptions of the River Brent Restoration Project, Tokyngton Park, London, BSc (Geography) Thesis. Queen Mary, University of London, London UK. January 2007.

Apostolaki S (undated) SR 622: An Assessment of the Social Impacts of Sustainable Drainage Systems in the UK. www.ciria.org.uk/suds/pdf/social_impact_summary.pdf. Verified 20 January 2011.

Apostolaki, S (2007). The Social Dimension of Stormwater Management Practices Including Sustainable Urban Drainage Systems and River Management Options. PhD Thesis. University of Abertay Dundee. Dundee, Scotland. January 2007.

Bender, J. and Phillips, P. (2004) Microbial mats for multiple applications in aquaculture and bioremediation. Bioresource Technology 94: 3, 229-238.

Berndtsson, J.C. (2010) Green roof performance towards management of runoff water quantity and quality: A review. Ecological Engineering 36: 4, 351-360.

Bromley, C. (2010) Personal Communication with C Bromley, Senior Hydromorphologist, Scottish Environment Protection Agency, Stirling, Scotland.

Brundtland, G. (1987) Our Common Future: Report of the World Commission on Environment and Development - A/42/427. Editor: Brundtland, G., Oxford, UK: Oxford University Press.

Carter, T. and Jackson, C.R. (2007) Vegetated roofs for stormwater management at multiple spatial scales. Landscape and Urban Planning; 80: 1-2, 84-94.

Castleton, H.F., Stovin' V., Beck, S.B.M. and Davison, J.B. (2010) Green roofs; building energy savings and the potential for retrofit. Energy and Buildings 42: 10, 1582-1591. 
Chin, A. 2006: Urban transformation of river landscapes in a global context. Geomorphology 79: 3-4, 460-487.

Cho, K.H., Pachepsky, Y.A., Kim, J.H., Guber, A.K., Shelton, D.R. and Rowland, R. (2010) Release of Escherichia coli from the bottom sediment in a first-order creek: Experiment and reach-specific modeling Journal of Hydrology 391: 3-4, 322-332.

Crabill, C., Donald' R., Snelling, J., Foust, R. and Southam' G. (1999) The impact of sediment fecal coliform reservoirs on seasonal water quality in Oak Creek, Arizona. Water Research, 33, 9, 2163-2171.

D'Arcy, B. and Frost, A. (2001) The role of best management practices in alleviating water quality problems associated with diffuse pollution. The Science of The Total Environment 265: 1-3, 359367.

Davies, Z.G., Fuller' R.A., Loram, A., Irvine, K.N., Sims, V.and Gaston. K.J (2004) A national scale inventory of resource provision for biodiversity within domestic gardens. Biological Conservation 142: 4, 761-771.

DayWater BMP catalogue (2005) Best Management Practice (BMP) Catalogue. http://daywater.in2p3.fr/EN/indexFM.php?section=bmp\&new=1. Verified 21 January 2011.

Decaëns, T., Jiménez, J.J., Gioia, C., Measey, G.J. and Lavelle, P. (2006) The values of soil animals for conservation biology. European Journal of Soil Biology 42; 1, S23-S38.

Defra (2010) Natural Environment: adapting to climate change. http://www.defra.gov.uk/environment/climate/documents/natural-environment-adaptation.pdf. Verified 31 January 2011.

Defra (2007) Securing a healthy natural environment: an action plan for embedding an ecosystems approach. London, UK: Defra Publications.

de Groot, R.S., Alkemade, R., Braat, L., Hein, L. and Willemen, L. (2010) Challenges in integrating the concept of ecosystem services and values in landscape planning, management and decision making. Ecological Complexity: 7, 3, 260-272.

de Miguel' E., Charlesworth, S., Ordóñez,' A. and Seijas, E. (2005) Geochemical fingerprints and controls in the sediments of an urban river: River Manzanares, Madrid (Spain) Science of The Total Environment 340: 1-3, 137-148.

Desai, C., Pathak H, and Madamwar, D. (2010) Advances in molecular and "-omics" technologies to gauge microbial communities and bioremediation at xenobiotic/anthropogen contaminated sites. Bioresource Technology 101: 6, 1558-1569.

Deyong, Y., Hongbo, S., Peijun, S., Wenquan, Z. and Yaozhong, P. (2009) How does the conversion of land cover to urban use affect net primary production? A case study in Shenzhen city, China. Agricultural and Forest Meteorology 149: 11, 2054-2060.

EA (2006) Bringing your rivers back to life. A guide to restoring rivers in North London. Environment Agency for England and Wales, Thames Region, NE Area Office: Hatfield.

EA (2002) River restoration: A stepping stone to urban regeneration highlighting the opportunities in South London. Environment Agency for England Wales, Reading, UK. ISBN: 1857059042.

EA (undated) The River Brent enhancement project, Wembley. Environmental Agency for England and Wales. Reading, UK.

EA (undated) River Brent Geomorphological Assessment. Babtie, Brown and Root (BBR Report Number: BWA290055 
England, J. (2004) River Brent Restoration Project: Tokyngton Park macroinvertebrate and habitat post project survey. Environmental Agency for England and Wales. Reading, UK.

Eriksson, E., Baun, A., Scholes, L., Ledin, A., Ahlman, A.S., Revitt, M., Noutsopoulos,'C. and Mikkelsen' P.S. (2007) Selected stormwater priority pollutants - a European perspective. Science of The Total Environment 383: 1-3, 41-51.

EU Environmental Quality Standards Directive (2008) Directive 2008/105/EC of the European Parliament and of the Council of 16 December 2008 on environmental quality standards in the field of water policy. http://ec.europa.eu/environment/water/water-dangersub/index.htm. Verified 3 August 2010.

EU Floods Directive 2007: Directive 2007/60/EC of the European Parliament and of the Council of 23 October 2007 on the assessment and management of flood risks. http://eurlex.europa.eu/LexUriServ/LexUriServ.do?uri=OJ:L:2007:288:0027:01:EN:HTML. Verified 2 August 2010

EU WFD (2000) Directive 2000/60/EC of the European Parliament and of the Council of 23 October 2000 establishing a framework for Community action in the field of water policy Water Framework Directive. http://eur-lex.europa.eu/LexUriServ/LexUriServ.do?uri=CELEX:32000L0060:EN:HTML. Verified 2 August 2010.

Galvao, T.C., Mohn, W.W. and Lorenzo, V. (2005) Exploring the microbial biodegradation and biotransformation gene pool, Trends in Biotechnology 23: 497-506.

Hatt, B.E., Deletic, A. and Tim D. Fletcher, T.D. (2006) Integrated treatment and recycling of stormwater: a review of Australian practice. Journal of Environmental Management 79: 1, 102-113.

JDC (2010) Oregon takes on hydropower projects. Journal of Daily Commerce. http://www.oregonbusiness.com/high-five/10-high-five/3638-cities-pursue-micro-hydropower.

Verified31 January 2011.

Jefferies, C., Aitken, A., McLean, N., Macdonald, K. and McKissock G. (1999) Assessing the performance of urban BMPs in Scotland. Water Science and Technology 39: 12, 123-131.

Karlsson, K., Viklander, M., Scholes, L. and Revitt, M. (2010) Heavy metal concentrations and toxicity in water and sediment from stormwater ponds and sedimentation tanks. Journal of Hazardous Materials 178: 1-3, 612-618.

Kazemi, F., Beecham' S., Gibbs, J. and Clay,' R. (2009) Factors affecting terrestrial invertebrate diversity in bioretention basins in an Australian urban environment. Landscape and Urban Planning 92: 3-4, 304-313.

Krüger, E.L. and Pearlmutter, D. (2008) The effect of urban evaporation on building energy demand in an arid environment. Energy and Buildings 40: 11, 2090-2098.

Landrigan, P.J., Kimmel, C.A., Correa, A., \& Eskenazi, B. (2004). Children's health and the environment: Public health issues and challenge for risk assessment. Environmental Health Perspectives 112: 257-265.

Le Viol, I., Mocq, J., and Julliard, R., and Kerbiriou, C., (2009) The contribution of motorway stormwater retention ponds to the biodiversity of aquatic macroinvertebrates. Biological Conservation 142: 12, 3163-3171.

Lloyd, S.D., Wong, T.H.F. and Chesterfield C.J. (2002) Water Sensitive Urban Design - A Stormwater Management Perspective. Industry Report $02 / 10$ by the Cooperative Research Centre for Catchment Hydrology and Melbourne Water Corporation.. September 2002. http://www.clearwater.asn.au/resources/ 291_1.pdf. 
Maas, J., Verheij, R.A., P Groenewegen, P.P., Vries. S. and Spreeuwenberg. P. (2006) Green space, urbanity, and health: how strong is the relation? Journal of Epidemiology and Community Health 60: 587-592.

Madlener, R. and Sunak, Y (2010) Impacts of urbanization on urban structures and energy demand: What can we learn for urban energy planning and urbanization management? Sustainable Cities and Society doi:10.1016/j.scs.2010.08.006.

Makropoulos, C.K., Natsis, K., Liu, S., Mittas, K. and Butler, D. (2008) Decision support for sustainable option selection in integrated urban water management. Environmental Modelling \& Software 23: 12, $1448-1460$.

Mayor of London (undated) London ton tap. http://www.londonontap.org/qanda/. Verified 31 January 2011.

McMullan (2007) Process/ecology interactions in a recently restored urban river, with particular reference to contaminated sediments: A case study from the River Brent, London. MSc Thesis (Urban Water and Environmental Management) University of Abertay Dundee.

MEA (2005) Chapter 2: Ecosystems and their senvices. In: Ecosystems and Human Well-being A Framework for Assessment. http://www.maweb.org/en/Framework.aspx. Verified 31 January 2011.

Merete Muthanna, T., Viklander, M., Godecke Blecken, G., and Sveinn T. Thorolfsson (2007) Snowmelt pollutant removal in bioretention areas. Water Research 41: 18, 4061-4072.

Milesi, C., Elvidge, C.D., Ramakrishna R., Nemani, R.R. and Running, S.W. (2003) Assessing the impact of urban land development on net primary productivity in the southeastern United States Remote Sensing of Environment 86: 3, 401-410.

Minet Kinge, J. and Morris, S. (2010) Socioeconomic variation in the impact of obesity on health related quality of life. Social Science \& Medicine 71: 10, 1864-1871.

Montalto' F., Behr' C, Alfredo, K., Wolf, M., Arye' M., and Walsh' M. (2007) Rapid assessment of the cost-effectiveness of low impact development for CSO control. Landscape and Urban Planning 82, 3, $117-131$.

Mooney H., Larigauderie A., Cesario M., Elmquist T., Hoegh-Guldberg O., Lavorel S., Mace GM., Palmer M., Scholes R. and Yahara T. 2009: Biodiversity, climate change, and ecosystem services. Current Opinion in Environmental Sustainability 1:1, 46-54.

Nakova, E., Linnebank, F.E., Bredeweg, B., Salles, P. and Uzunov' Y. (2009) The river Mesta case study: A qualitative model of dissolved oxygen in aquatic ecosystems. Ecological Informatics 4, 5-6, 339-357.

NHS (2010) In-patients formally detained in hospitals under the Mental Health Act 1983 and patients subject to supervised community treatment, Annual figures, England 2009/10. http://www.ic.nhs.uk/pubs/inpatientdetmha0910. Verified 20/1/11.

Nyman, J. A., Delaune, R. D. and Patrick, W. H. (1990) Wetland soil formation in the rapidly subsiding Mississippi River Deltaic Plain: Mineral and organic matter relationships. Estuarine, Coastal and Shelf Science 31: 1, 57-69.

Osmanoğlu, B., Dixon, T.H., Wdowinski, S., Cabral-Cano,E. and Jiang, Y. (2011) Mexico City subsidence observed with persistent scatterer InSAR. International Journal of Applied Earth Observation and Geoinformation 13: 1, 1-12.

Pieniak, Z. , Federico Pérez-Cueto, F., and Wim Verbeke, W. (2009) Association of overweight and obesity with interest in healthy eating, subjective health and perceived risk of chronic diseases in three European countries. Appetite 53: 3, 399-406. 
Postel, S. and Carpenter, S. (1997) Freshwater ecosystem services. In: Daily, G. (ed.) Nature's services. Washington, D.C., USA: Island Press,

Punys, P. and Pelikan, B. (2007) Review of small hydropower in the new Member States and Candidate Countries in the context of the enlarged European Union. Renewable and Sustainable Energy Reviews 11: 7, 1321-1360.

RCEP (2007) Royal Commission on Environmental Pollution - Urban Nature. http://www.rcep.org.uk/urban/urbannature.pdf. Verified 28 July 2010.

Rijsberman, F.R. (2006) Water scarcity: Fact or fiction? Agricultural Water Management 80: 1-3, 5-22.

Rudge, S., Staff, M., Capon, A. and Paepke, O. (2008) Serum dioxin levels in Sydney Harbour commercial fishers and family members. Chemosphere 73: 10, 1692-1698.

Saint-Laurent, D., St-Laurent' J., Lavoie' L. and Ghaleb,'B. (2008) Use geopedological methods for the evaluation of sedimentation rates on river floodplains, southern Québec, Canada. CATENA 73: 3, 321-337.

Scharenbroch, B.C., Lloyd, J.E.' and Johnson-Maynard, J.L. (2005) Distinguishing urban soils with physical, chemical, and biological properties. Pedobiologia 49: 4, 283-296.

Scholes, L., Faulkner, HP., Tapsell, S. and Downward, S. 2008: Urban rivers as pollutant sinks and sources: a public health concern to recreational river users? Water, Air and Soil Pollution Focus 8:5-6, 543-553.

Semadeni-Davies' A., Hernebring, C., Svensson, G. and Gustafsson, L;G (2008) The impacts of climate change and urbanisation on drainage in Helsingborg, Sweden: Suburban stormwater. Journal of Hydrology 350: 1-2, 114-125.

SESAC (undated) Mini-hydropower in Viscose. http://www.concerto-sesac.eu/spip.php?rubrique59. Verified31 January 2011.

Shi, P-J., Yuan, Y., Zheng, J., Wang, J-A., Ge'Y. and Qiu, G-Y. (2007) The effect of land use/cover change on surface runoff in Shenzhen region, China. CATENA 69: 1, 31-35

Skinner, K.S., \& Bruce-Burgess, L. (2005). Strategic and project-level river restoration protocols-key components for meeting the requirements of the water framework directive (WFD). Water and Environment Journal 19: 2, 135-142.

UN (2009) World Urbanization Prospects: The 2009 Revision. http://esa.un.org/unpd/wup/index.htm. Verified 31 January 2011.

UN Convention on Biodiversity (1992) Convention on Biodiversity. http://www.cbd.int/convention/text/. Verified 31 January 2011.

UN Habitat (2008) State of the World's Cities 2010/2011 Bridging the Urban Divide. London, UK: Earthscan.

USGS (2010) Hydroelectric power water use. http://ga.water.usgs.gov/edu/wuhy.html. Verified 31 January 2011.

van den Berg A.E., Maas, J., Verheij, R.A., P Groenewegen, P.P. (2010)Green space as a buffer between stressful life events and health. Social Science \& Medicine 70: 1203-1210.

Villarreal, E. L. Semadeni-Davies, A. and Bengtsson L. (2004) Inner city stormwater control using a combination of best management practices. Ecological Engineering 22: 4-5, 279-298. 
Wang, X., Chen, W., Zhang, L., Jin, D. and Lu, C. (2010) Estimating the ecosystem service losses from proposed land reclamation projects: A case study in Xiamen. Ecological Economics 69: 12, 2549-2556.

Ward Thompson, C. (2010) Linking landscape and health: The recurring theme. Landscape and Urban Planning 99: 3-4, 187-195.

White, M., Smith, A., Humphryes, K., Pahl, S., Snelling, D., Depledge, M. (2010) Blue space: The importance of water for preference, affect, and restorativeness ratings of natural and built scenes. Journal of Environmental Psychology 30; 4, 482-493.

Wilby, RL. and Perry, GLW. (2006): Climate change, biodiversity and the urban environment: a critical review based on London, UK. Progress in Physical Geography 30, 1, 73-98.

Yamagata, H., Nasu, M., Yoshizawa, M., Miyamoto, A. and Minamiyama, M. (2008) Heat island mitigation using water retentive pavement sprinkled with reclaimed wastewater. Water Science and Technology 57: 5, 763-772.

Yang, B. and LI, M-H. (2010) Ecological engineering in a new town development: Drainage design in The Woodlands, Texas. Ecological Engineering 36: 12, 1639-1650. 